\title{
Humbert's Self-defence for His Relation With Lolita
}

\author{
PANG Ren-shan \\ Shandong University of Science and Technology, Qingdao, Shandong, China
}

\begin{abstract}
In Vladimir Nabokov's novel Lolita, we can find that Humbert tries to defend himself for his relation with Lolita. Humbert says Lolita has a precursor that is Annabel. That is pure love between children. Pure love is innocent, so Humbert wants to say he is not to blame. His relation with Lolita is pure love. In addition, Edgar Allan Poe wrote a poem about Annabel Lee. And Humbert wants to say that it is the poem that makes him love Lolita.
\end{abstract}

Keywords: precursor, Humbert, self-defence, relation, Lolita, Edgar Allan Poe, Dante

\section{Introduction}

On page nine, in paragraph two and three of chapter one, the novel has the following words:

She was Lo, plain Lo, in the morning, standing four feet ten in one sock. She was Lola in slacks. She was Dolly at school. She was Dolores on the dotted line. But in my arms she was always Lolita. (Nabokov, 2000, p. 9)

Did she have a precursor? She did, indeed she did. In point of fact, there might have been no Lolita at all had I not loved, one summer, a certain initial girl-child. In a princedom by the sea. Oh when? About as many years before Lolita was born as my age was that summer. You can always count on a murderer for a fancy prose style. (Nabokov, 2000, p. 9)

From the above words, we can know that Humbert is trying to defend himself by saying that there is a precursor. Because there is a precursor, Humbert substitutes Lolita for the precursor. His love of the precursor is innocent love, therefore, his love of Lolita is also innocent pure love.

\section{The Precursor}

In defending himself, Hunbert mentions the precursor. In chapter three, the novel Lolita has the following words in narating the precursor:

Annabel was, like the writer, of mixed parentage: half-English, half-Dutch, in her case. I remember her features far less distinctly today than I did a few years ago, before I knew Lolita. There are two kinds of visual memory: one when you skillfully recreate an image in the laboratory of your mind, with your eyes open (and then I see Annabel in such general terms as: "honey-colored skin", "think arms", "brown bobbed hair", "long lashes", "big bright mouth"); and the other when you instantly evoke, with shut eyes, on the dark inner side of your eyelids, the objective, absolutely optical replica of a beloved face, a little ghost in natural colors (and this is how I see Lolita). Let me therefore primly limit myself, in describing Annabel, to saying she was a lovely child a few months my junior. Her parents were old friends of my aunt's, and as stuffy as she. They had rented a villa not far from Hotel Mirana. Bald brown Mr. Leigh and fat, powdered Mrs. Leigh (born Vanessa van Ness). How I loathed them. At first, Annabel and I talked of peripheral affairs. She kept lifting handfuls of fine sand and letting it pour through her fingers. Our brains were turned the way those of intelligent European preadolescents were in our day and set, and I doubt if much individual genius should be assigned to our interest

PANG Ren-shan, associate professor, master, College of Foreign Languages, Shandong University of Science and Technology. 
in the plurality of inhabited worlds, competitive tennis, infinity, solipsism, and so on. The softness and fragility of baby animals caused us the same intense pain. She wanted to be a nurse in some famished Asiatic country; I wanted to be a famous spy. All at once we were madly, clumsily, shamelessly, agonizingly in love with each other; hopelessly, I should add, because that frenzy of mutual possession might have been assuaged only by our actually imbibing and assimilating every particle of each other's soul and flesh; but there we were, unable even to mate as slum children would have so easily found an opportunity to do. After one wild attempt we made to meet at night in her garden (of which more later), the only privacy we were allowed was to be out of earshot but not out of sight on the populous part of the plage. There, on the soft sand, a few feet away from our elders, we would sprawl all morning, in a petrified paroxysm of desire, and take advantage of every blessed quirk in space and time to touch each other: her hand, half-hidden in the sand, would creep toward me, its slender brown fingers sleepwalking nearer and nearer; the $\mathrm{n}$, her opalescent knee would start on a long cautious journey; sometimes a chance rampart built by younger children granted us sufficient concealment to graze each other's salty lips; these incomplete contacts drove our healthy and inexperienced young bodies to such a state of exasperation that not even the cold blue water, under which we still clawed at each other, could bring relief. Among some treasures I lost during the wanderings of my adult years, there was a snapshot taken by my aunt which showed Annabel, her parents and the staid, elderly, lame gentleman, a Dr. Cooper, who that same summer courted my aunt, grouped around a table in a sidewalk cafe. Annabel did not come out well, caught as she was in the act of bending over her chocolat glace, and her thin bare shoulders and the parting in her hair were about all that could be identified (as I remember that picture) amid the sunny blur into which her lost loveliness graded; but I, sitting somewhat apart from the rest, came out with a kind of dramatic conspicuousness: a moody, beetle-browed boy in a dark sport shirt and well-tailored white shorts, his legs crossed, sitting in profile, looking away. That photograph was taken on the last day of our fatal summer and just a few minutes before we made our second and final attempt to thwart fate. Under the flimsiest of pretexts (this was our very last chance, and nothing really mattered) we escaped from the cafe to the beach, and found a desolate stretch of sand, and there, in the violet shadow of some red rocks forming a kind of cave, had a brief session of avid caresses, with somebody's lost pair of sunglasses for only witness. I was on my knees, and on the point of possessing my darling, when two bearded bathers, the old man of the sea and his brother, came out of the sea with exclamations of ribald encouragement, and four months later she died of typhus in Corfu. (Nabokov, 2000, pp. 11-13)

The above words in the novel tell the readers that the precursor is Annabel, and Humbert enjoys a pure innocent love with his girlfriend Annabel. That love should not be blamed at all, because the love is pure, innocent, and natural.

In chapter four, the novel continues to tell the readers Humbert's cherish of Annabel. The novel has the following words:

I leaf again and again through these miserable memories, and keep asking myself, was it then, in the glitter of that remote summer, that the rift in my life began; or was my excessive desire for that child only the first evidence of an inherent singularity? When I try to analyze my own cravings, motives, actions and so forth, I surrender to a sort of retrospective imagination which feeds the analytic faculty with boundless alternatives and which causes each visualized route to fork and re-fork without end in the maddeningly complex prospect of my past. I am convinced, however, that in a certain magic and fateful way Lolita began with Annabel.

I also know that the shock of Annabel's death consolidated the frustration of that nightmare summer, made of it a permanent obstacle to any further romance throughout the cold years of my youth. The spiritual and the physical had been blended in us with a perfection that must remain incomprehensible to the matter-of-fact, crude, standard-brained youngsters of today. Long after her death I felt her thoughts floating through mine. Long before we met we had had the same dreams. We compared notes. We found strange affinities. The same June of the same year (1919) a stray canary had fluttered into her house and mine, in two widely separated countries. Oh, Lolita, had you loved me thus I have reserved for the conclusion of my "Annabel" phase the account of our unsuccessful first tryst. One night, she managed to deceive the vicious vigilance of her family. In a nervous and slender-leaved mimosa grove at the back of their villa we found a perch on the ruins of a low stone wall. Through the darkness and the tender trees we could see the arabesques of lighted windows which, touched up by the colored inks of sensitive memory, appear to me now like playing cards presumably 
because a bridge game was keeping the enemy busy. She trembled and twitched as I kissed the corner of her parted lips and the hot lobe of her ear. A cluster of stars palely glowed above us, between the silhouettes of long thin leaves; that vibrant sky seemed as naked as she was under her light frock. I saw her face in the sky, strangely distinct, as if it emitted a faint radiance of its own. Her legs, her lovely live legs, were not too close together, and when my hand located what it sought, a dreamy and eerie expression, half-pleasure, half-pain, came over those childish features. She sat a little higher than I, and whenever in her solitary ecstasy she was led to kiss me, her head would bend with a sleepy, soft, drooping movement that was almost woeful, and her bare knees caught and compressed my wrist, and slackened again; and her quivering mouth, distorted by the acridity of some mysterious potion, with a sibilant intake of breath came near to my face. She would try to relieve the pain of love by first roughly rubbing her dry lips against mine; then my darling would draw away with a nervous toss of her hair, and then again come darkly near and let me feed on her open mouth, while with a generosity that was ready to offer her everything, my heart, my throat, my entrails, I have her to hold in her awkward fist the scepter of my passion. I recall the scent of some kind of toilet powder I believe she stole it from her mother's Spanish maid a sweetish, lowly, musky perfume. It mingled with her own biscuity odor, and my senses were suddenly filled to the brim; a sudden commotion in a nearby bush prevented them from overflowing and as we drew away from each other, and with aching veins attended to what was probably a prowling cat, there came from the house her mother's voice calling her, with a rising frantic note and Dr. Cooper ponderously limped out into the garden. But that mimosa grove - the haze of stars, the tingle, the flame, the honey-dew, and the ache remained with me, and that little girl with her seaside limbs and ardent tongue haunted me ever since until at last, twenty-four years later, I broke her spell by incarnating her in another. (Nabokov, 2000, pp.13-15)

From the above words from the novel, the readers can know that Humbert cannot forget Annabel, and it is a spell that can not be broken untill Lolita appears. Before Lolita, Humbert only cherishes Annabel, and he has no interest in other girls. Lolita is the incarnation of Annabel, a substitute for Annabel. In this way, Humbert tries to defend his relation with Lolita: Because Humbert's love of Annabel is pure and innocent, and Lolita is the incarnation of Annabel, Humbert's relation with Lolita is also pure and innocent. That is Humbert's self-defence.

\section{Adgar Allen Poe's Poem}

In chapter one and chapter ten, Humbert mentions "princedom by the sea" two times. And Humbert mentions "Annabel" many times. Here both "annabel" and "princedom by the sea" allude to "Annabel Lee" by Adgar Allen Poe. The annotated Lolita has this poem:

It was many a year ago, In a kindom by the sea, That a maiden there lived whom you may know By the name of Annabel Lee;- And this maiden she lived with no other thought That to love and be loved by me. She was a child and I was a child, In this kingdom by the sea, But we loved with a love that was more than love-I and my Annabel Lee-With a love that the winged seraphs of Heaven Coveted her and me. And this was the reason that, long ago, In this kingdom by the sea, A wind blew out of a cloud by night Chilling my Annabel Lee; So that her high-born kinsmen came And bore her away from me, To shut her up in a sepulchre In this kingdom by the sea. The angels, not half so happy in Heaven, Went envying her and me:-Yes! that was reason (as all men know, In this kingdom by the sea) That the wind came out of the cloud, chilling And killing my Annabel Lee. But our love it was stronger by far than the love Of those who were older than we- Of many far wiser than we-And neither the angels in Heaven above Nor the demons down under the sea Can ever dissever my soul from the soul Of the beautiful Annabel Lee:-For the moon never beams without bringing me dreams Of the beautiful Annabel Lee; And the stars never rise but I see the bright eyes Of the beautiful Annabel Lee; And so, all the night-tide, I lie down by the side Of my darling, my darling, my life and my bride In her sepulchre there by the sea-In her tomb by the sounding sea. (Nabokov, 2000, pp. 329-330)

From the above poem, the readers can know that Humbert wants to say the poem makes him have the relation with Lolita. Because the precursor is Annabel, and Humbert enjoys the love with Annabel in a princedom by the sea. Lolita is the incarnation of Annabel. 


\section{Conclusion}

Hunbert mentions the precursor Annabel he associated with in a princedom by the sea. That love is pure and innocent, so Humbert wants to say he should not be blamed. In addition, Humbert says that Lolita is the incarnation of Annabel. Because Humbert says he loves no other girls than Annabel, he loves Lolita who is the incarnation of Annabel. His love of Lolita is also pure anf innocent. Both "Annabel" and "princedom by the sea"

allude to Adgar Allen Poe's poem Annabel Lee. This poem narrates the pure and innocent love between "I" and "Annabel Lee", so Hunbert wants to say that it is the poem that makes him do so, and he should not be blamed. That is the self-defence of Humbert for his relation with Lolita.

\section{References}

Hawthorne, N. (1986). The scarlet letter. New York: Bantam Books.

LIU, J. L. (2004). On Nabokov's concept of literature. Journal of Yangzhou University (Humanities \& Social Sciences), 6, 33-38.

LUO, G. B. (2005). Language art of Lolita. Journal of Liaocheng University (Social Sciences), 2, 106-109.

Melville, H. (1981). Moby-Dick. New York: Bantam Books.

Nabokov, V. (2000). Lolita. London: Penguin Books.

PAN, L. F. (2004). Pursuing the enigma of humanity: An interpretation of two mysteries in Nabokov and Lolita. Journal of Social Science of Hunan Normal University, 4, 115-118.

WANG, Q. S. (2003). Returning to realism: A type of decoding Lolita. Journal of Shanghai Teacher's University (Phylosophy \& Social Sciences), 3, 88-93.

YANG, Z. Y. (2002). God is in the detail: An expat iation on the novel Lolita. Foregn Literature, 2, 82-86. 